\title{
DEWOCJONALIA W MIESZCZAŃSKICH INWENTARZACH POŚMIERTNYCH Z TERENU MAŁOPOLSKI (XVI-XVIII WIEK)
}

\section{Devotional items in bourgeois post-humous inventories of Lesser Poland (16th-18th centuries)}

Abstract

In posthumous inventories, which constitute a kind of material summary of life, one can find various kinds of movables, arranged according to specific categories. Among them there were also devotional items, which, however, constitute a part of the legacy that escapes easy classification. Some of them may have been used as elements of interior decoration (paintings, sculptures, crucifixes). On the other hand, religious symbols in the form of crosses, Agnus Deis or rosaries, indicated certain spiritual needs of their wearers and the same time testified to their wealth. Despite the fact that the number of posthumous inventories containing devotional items was not particularly impressive, even in such a modest juxtaposition we can see which artefacts enjoyed greater popularity during the analysed centuries. Most frequently mentioned were crosses and rosaries, and in the 17th century, additionally, Agnus Deis.

Keywords: devotional articles, posthumous inventory, towns, burghers, Lesser Poland

\begin{abstract}
Abstrakt
W inwentarzach pośmiertnych, stanowiących pewnego rodzaju materialne podsumowanie życia, odnaleźć można różnego rodzaju ruchomości, uporządkowane według określonych kategorii. Wśród nich znajdowały się również dewocjonalia, stanowiące jednak część spuścizny umykającą łatwym klasyfikacjom. Niektóre z nich mogły stanowić element wyposażenia wnętrz (obrazy, rzeźby, krucyfiksy). Natomiast symbole religijne w postaci krzyżyków, agnusków czy różańców, wskazywały na pewne potrzeby natury duchowej noszących je osób, a jednocześnie świadczyły o ich zamożności. Mimo, że liczba inwentarzy pośmiertnych, w których notowano dewocjonalia nie była szczególnie imponująca, to nawet w tak skromnym zestawieniu widać, jakie artefakty na przestrzeni analizowanych stuleci, cieszyły
\end{abstract}

Adiunkt w Instytucie Historii UJK w Kielcach. Zainteresowania badawcze: mieszczańskie testamenty i inwentarze pośmiertne, prawo spadkowe i rodzina mieszczańska w okresie nowożytnym, życie codzienne w małych miastach Małopolski w dobie staropolskiej. E-mail: kajus@ujk.edu.pl. 
się większą popularnością. Najczęściej wymieniano bowiem krzyżyki i różańce, a w XVII wieku dodatkowo agnuski.

Słowa kluczowe: dewocjonalia, inwentarz pośmiertny, miasta, mieszczanie, Małopolska

$\mathrm{I}_{\mathrm{i}=\mathrm{m}}^{\mathrm{n}}$ nwentarz pośmiertny jako „urzędne popisanie rzeczy” zakładał spisanie całości spuścizny, jaka pozostała po zmarłym. Miały to być dobra ruchome i nieruchomości oraz gotówka, w tym wierzytelności i długi. Bartłomiej Groicki, XVI-wieczny znawca i komentator prawa magdeburskiego, zwracał uwagę na „pożytki” płynące z faktu sporządzenia pośmiertnego rejestru mienia, przede wszystkim dla spadkobierców zmarłego, mogących w ten sposób określić nie tylko wielkość obejmowanego spadku, ale i stopień jego zadłużenia. Groicki szczególnie mocno podkreślał wagę sporządzenia inwentarza dla nieletnich spadkobierców, dla których objęcie schedy następowało w dłuższej perspektywie czasowej, po kilkuletnim okresie oczekiwania. „Dobrodziejstwo inwentarza” oznaczało również możliwość odrzucenia schedy w momencie, gdyby wielkość długów znacznie przekraczała jej wartość, a spadkobiercy nie byliby w stanie ich uregulować2 .

W inwentarzach pośmiertnych, stanowiących więc pewnego rodzaju finansowe podsumowanie i zamknięcie czyjegoś życia, wymieniane są różnego rodzaju ruchomości, uporządkowane według określonych kategorii, czy to z racji funkcji przypisywanej danemu przedmiotowi, czy jego surowca. Wśród spisywanych mobiliów znajdowały się również dewocjonalia, stanowiące jednak część spuścizny, którą trudno jednak poddać prostej klasyfikacji ${ }^{3}$. Niektóre z nich, takie jak obrazy, rzeźby oraz krucyfiksy, mogły bowiem stanowić element wyposażenia wnętrz mieszczańskich domów. Natomiast symbole religijne w postaci krzyżyków, medalików czy agnusków, wskazywały na pewne potrzeby natury duchowej noszących je osób, a jednocześnie świadczyły o ich zamożności, szczególnie gdy były wykonane $\mathrm{z}$ metali szlachetnych.

Dewocjonalia miały więc wśród ruchomości swój swoisty status, stojąc niejako na pograniczu sfery sacrum i profanum. Z jednej strony stanowiły dekorację wnętrz, z drugiej ukazywały mieszczańską religijność, a przez to wrażliwość i potrzebę indywidualnej pobożności czy chęć budowania prywatnej przestrzeni służącej do modlitwy i kontemplacji. Zapewne też w jakimś stopniu występowanie w pośmiertnych rejestrach mienia tego rodzaju przedmiotów wynikało z chęci pokazania czy podkreślenia własnego statusu materialnego.

Analiza inwentarzy pośmiertnych spisanych w średnich i małych ośrodkach miejskich z terenu Małopolski pokazuje, że dewocjonalia rzadko bywały notowane w mieszczańskich rejestrach ${ }^{4}$. W zachowanych do dnia dzisiejszego księgach miejskich, pochodzących z ponad 60 miast i miasteczek, wpisanych zostało niemal 616 inwentarzy pośmiertnych. Dla drugiej

\footnotetext{
2 B. Groicki, Obrona sierot $i$ wdów, oprac. K. Koranyi, Warszawa 1958, s. 26-45, 54-57; idem, Porzadek sadów i sprawa miejskich prawa majdeburskiego w Koronie Polskiej, oprac. K. Koranyi, Warszawa 1953, s. 175-177.

3 M. Pisarzak, Dewocjonalia, w: Encyklopedia katolicka, t. 3, red. R. Łukaszyk, L. Bieńkowski, F. Gryglewicz, Lublin 1985, kol. 1226; M. Kołyszko, Dewocjonalia z końca XVI-XVIII wieku pochodzace z badań archeologicznych na terenie Polski (stan zachowania, identyfikacja, zagadnienia konserwatorskie), Torun 2013, s. 22-169.

4 Podobnie wyglądała sytuacja w inwentarzach pośmiertnych pochodzących ze stołecznego Krakowa, analizowanych przez Monikę Saczyńską. Zob. M. Saczyńska, Mieszczan krakowskich domowe świętości, czyli wyobrażenia dewocyjne w przestrzeni prywatnej (przykłady wczesnonowożytne), w: Rzeczy i ludzie. Kultura materialna w późnym średniowieczu i w okresie nowożytnym. Studia dedykowane Marii Dąbrowskiej, red. M. Bis, W. Bis, Warszawa 2014, s. 275.
} 
połowy XVI wieku było ich 167, a w następnym stuleciu już 400, przy czym należy zaznaczyć, że zdecydowana większość z nich (293 zapisy), pochodziła z pierwszej połowy XVII wieku. W kolejnym stuleciu ilość inwentarzy pośmiertnych wpisanych do ksiąg miejskich uległa drastycznemu zmniejszeniu (49 rejestrów), a większość z nich pochodziła z drugiej połowy XVIII wieku (35 spisów). W szesnastowiecznych inwentarzach dewocjonalia zostały wymienione w 13 zapisach (co stanowi niecałe 8\% ogólnej liczby zachowanych zapisów). W XVII wieku takich rejestrów było 38 (prawie 10\% spisów), a w kolejnym stuleciu 7 (20\% zapisów) $)^{5}$.

Mimo że liczba inwentarzy pośmiertnych, w których notowano dewocjonalia, nie była szczególnie imponująca, to nawet w tak skromnym zestawieniu widać, jak na przestrzeni analizowanych stuleci zmieniały się ludzkie preferencje i jakie artefakty cieszyły się większą popularnością. Zjawisko to nie było typowe jedynie dla małopolskich miast i miasteczek, podobne tendencje występowały również w inwentarzach mieszczan poznańskich ${ }^{6}$.

Popularne dewocjonalia, takie jak krzyżyki, agnuski czy różańce, szczególnie jeśli były wykonane ze srebra, kamieni szlachetnych czy pozłacane, notowano w inwentarzach pośmiertnych wśród kosztowności. Niezwykle rzadko zdarzało się, aby wyodrębniano je w osobny inwentarzowy dział. Wyjątkowo, w rejestrze wielickiego bednarza, Jana Szczypkowskiego (1756), stworzono oddzielną kategorię dla należących do niego dwudziestu dwu relikwiarzy ${ }^{7}$. Pojedynczy taki przypadek odnaleźć można również w źródłach poznańskich. W inwentarzu pośmiertnym służącej Elżbiety Topolskiej, spisanym w 1629 roku, utworzono osobny inwentarzowy dział, zatytułowany „Pacierze”, choć jednocześnie na początku rejestru odnotowano kategorię „Srebro, złoto”, w której znalazły się cenne dewocjonalia (na przykład cztery agnuski wykonane ze srebra). Natomiast wśród „Pacierzy” odnotowane zostały różańce (lub ich drobne elementy) wykonane z drewna, szkła, mosiądzu i piżma oraz kości ${ }^{8}$. Kryterium zastosowane przez urzędników spisujących mienie Topolskiej dotyczyło więc materiału, z którego wykonano dewocjonalia, a nie ich funkcji.

$\mathrm{W}$ inwentarzach pośmiertnych z małopolskich miasteczek najczęściej wspominanymi artefaktami były krzyżyki. W XVI wieku odnotowano zaledwie jeden taki rejestr i to pochodzący z końca stulecia (co stanowi 0,6\% spisanych wówczas inwentarzy pośmiertnych) 9 . Zdecydowanie częściej krzyżyki zaczęły się pojawiać w spisach pochodzących z XVII wieku (18 rejestrów), a szczególnie w drugiej połowie stulecia (12 spisów) ${ }^{10}$. Jednak nawet w tym stuleciu krzyżyki występowały zaledwie w 4,5\% wszystkich spisów. W XVIII wieku ponownie nastąpił spadek ilości inwentarzy, w których notowano tego rodzaju dewocjo-

\footnotetext{
K. Justyniarska-Chojak, Inwentarze pośmiertne z małych i średnich miast Małopolski (w XVI-XVIII wieku), Kielce 2020, s. 21-22.

6 Inwentarze mieszczańskie z lat 1528-1635 z ksiag miejskich Poznania, wyd. S. Nawrocki, J. Wisłocki, Poznań 1961; Inwentarze mieszczańskie z XVIII wieku z ksiag miejskich i grodzkich Poznania, t. 1: Z lat 1700-1758, wyd. J. Burszta, C. Łuczak, Poznań 1962; Inwentarze mieszczańskie z XVIII wieku z ksiąg miejskich i grodzkich Poznania, t. 2: 1759-1793, wyd. J. Burszta, C. Łuczak, Poznań 1965.

7 Archiwum Narodowe w Krakowie (dalej: ANK), Oddz. III, Akta miasta Wieliczki (dalej: Wieliczka), Odpisy $i$ wypisy $z$ akt radzieckich wielickich 1614-1763, sygn. 29/117/18, s. 920.

$8 \quad$ Inwentarze mieszczańskie, op. cit., s. 448-449 [nr 397].

9 Inwentarz pośmiertny Reginy Politkowej (1600) z Nowego Sącza. ANK, Oddz. III, Akta miasta Nowego Sącza (dalej: AmNS), Acta scabinalia (iudiciaria, criminalia) 1590-1604, sygn. 29/110/24, s. 125.

10 W XVII wieku krzyżyki odnotowane zostały w inwentarzach pośmiertnych pochodzących z ksiąg miejskich: Biecza, Kęt, Nowego Sącza, Pilzna.
} 
nalia. Krzyżyk pojawił się bowiem zaledwie w jednym inwentarzu pośmiertnym (czyli w 2\% wszystkich zachowanych dla XVIII wieku spisów) ${ }^{11}$. Analiza poznańskich rejestrów pośmiertnych, pochodzących z lat 1528-1635, pokazuje, że krzyżyki i w tych źródłach były najczęściej notowanymi artefaktami. Wymieniane były nawet dwa razy częściej niż różańce ${ }^{12}$.

Typowym zjawiskiem $\mathrm{w}$ inwentarzach pośmiertnych z małopolskich miast i miasteczek było występowanie pojedynczych krzyżyków i to bez względu na zamożność osób, których mienie spisywano, czy wielkość ośrodków miejskich, z których pochodzili. W zdecydowanej większości w rejestrach notowano krzyżyki wykonane ze srebra, rzadziej ze złota. Jedynie najbogatsi mieszkańcy większych ośrodków miejskich mogli sobie pozwolić na drogie krzyżyki ozdabiane szlachetnymi kamieniami, jak ksiądz Jan Tymowski (1655) z Nowego Sącza, który był właścicielem małego krzyżyka, zdobionego pięcioma rubinami, trzema perłami i „smelcem”"13. Mniej zamożni mieszczanie musieli się natomiast zadowolić posiadaniem krzyżyków wykonanych z innych metali niż srebro czy złoto. Do Krzysztofa Krynickiego (1693) z Nowego Sącza należał na przykład „krzyżyk z sześcią kamyków mosiężny”14.

Warto tym miejscu zwrócić uwagę na spisany w 1647 roku w Bieczu inwentarz pośmiertny Katarzyny Potrawczyny, właścicielki jatki rzeźniczej. Dysponowała ona dwoma krzyżykami i nie tylko ich liczba wyróżniała ten spis spośród innych, ale przede wszystkim kruszce, z których je wykonano ${ }^{15}$. Do Potrawczyny należał bowiem mały krzyżyk wykonany ze złota i większy ze srebra ${ }^{16}$. Warto również wspomnieć o spisie mienia należącego do Katarzyny Jaworki z Nowego Sącza, sporządzonym w 1653 roku. Odnotowane w nim zostały zarówno dwa krzyżyki (niewielki złoty i większy srebrny), jak i agnusek, a tego typu dewocjonalia zwykle występowały w inwentarzach osobno ${ }^{17}$.

Agnusek był rodzajem medalika z wizerunkiem Baranka Bożego lub Jana Chrzciciela wyciśniętym w wosku i oprawnym w srebro, bursztyn czy kryszta1 ${ }^{18}$. Taki właśnie ,agnusek

11 Srebrny krzyżyk odnotowany został w inwentarzu rzeczy, jakie pozostały po organiście Franciszku Góreckim z Czchowa, spisanym w 1708 roku. ANK, Oddz. I, Akta miasta Czchowa (dalej: Czchów), Proconsularia, consularia, advocatialia et scabinalia 1698-1716, sygn. 29/104/0/2/30, s. 742.

12 Inwentarze mieszczańskie, op. cit., s. 73 [nr 102], s. 95 [nr 135], s. 98 [nr 139], s. 109 [nr 152], s. 121 [nr 167], s. 127 [nr 174], s. 152 [nr 198], s. 186 [nr 220], s. 449 [nr 397], s. 489 [nr 411].

13 ANK, Oddz. III, AmNS, Acta scabinalia 1651-1658, sygn. 29/110/54, s. 686. W rejestrach poznańskich notowano na przykład krzyżyki z perłami, rubinami czy szafirami, których nie ma w spisach pochodzących z małopolskich miasteczek. Inwentarze mieszczańskie, op. cit., s. 152 [nr 198], s. 186 [nr 220], s. 489 [nr 411 ].

14 ANK, Oddz. III, AmNS, Acta scabinalia 1689-1694, sygn. 29/110/88, s. 39. Krzyżyk z identycznego materiału odnotowany został w inwentarzu Elżbiety Topolskiej (1629) z Poznania. Inwentarze mieszczańskie, op. cit., s. 449 [nr 397].

15 Dwa krzyżyki ze srebra wystąpiły w rejestrze pośmiertnym Jana Ćwiklińskiego (1674), mieszkańca Nowego Sącza. ANK, AmNS, Acta scabinalia 1671-1675, sygn. 29/110/62, s. 424.

16 ANK, Oddz. I, Akta miasta Biecza (dalej: Biecz), Księga lawnicza biecka 1639-1649, sygn. 29/101/0/2/17, s. 1134-1135. W inwentarzach poznańskich krzyżyki wykonane ze złota notowano równie sporadycznie. Inwentarze mieszczańskie, op. cit., s. 186 [nr 200], s. 489 [nr 411].

17 ANK, Oddz. III, AmNS, sygn. 29/110/54, s. 390.

18 I. Turnau, Stownik ubiorów. Tkaniny, wyroby pozatkackie, skóry, broń i klejnoty oraz barwy znane w Polsce od średniowiecza do początku XIX w., Warszawa 1999, s. 11; Agnusek, w: Stownik polszczyzny XVI wieku, t. 1: A-Bany, red. S. Bąk, M. R Mayenowa, F. Pepłowski, Wrocław-Warszawa-Kraków 1966, s. 91; M. Kołyszko, Dewocjonalia, op. cit., s. 70-72. Warto w tym miejscu wspomnieć pochodzący z 1706 roku rejestr Magdaleny Szumanowej, zamożnej mieszkanki Gdańska, w którym pojawiły się agnuski mające formę relikwiarza - „1 więlkię Agnusz Dęiey z obu stron za skłęm, w białych romach, stoięy ma wirschu ułtarzyka w t[y]lny izbię”. Gdański inwentarz mienia domowego Magdaleny Szumanowej z 1706 roku, oprac. i wyd. A.R. Chodyński, H. Dwilewicz, Wrocław-Warszawa-Kraków 1984, s. 44. O miejscach i sposobach eksponowania agnusków zob. J. Nowiński, 
kryształowy" wystąpił w rejestrze mienia Zygmunta Gądka alias Siedleckiego (1652) z Nowego Sącza ${ }^{19}$. Do bieckiego złotnika, Jakuba Szipa (1589), należał ,,agnusek maluczki jeden polski, srebrny"20. Znaczna popularność, jaką cieszyły się tego typu dewocjonalia, wynikała zapewne z przypisywanych im powszechnie właściwości ochronnych. Wierzono bowiem, że mają one szczególną moc zabezpieczającą nie tylko przed działaniem złych duchów i szatana, ale i chroniącą przed skutkami uderzenia pioruna, pożarem czy powodzią, oraz niezbędną osobom udającym się w podróż, kobietom w połogu i konającym² ${ }^{21}$.

Choć pierwszy raz agnusek został wymieniony w inwentarzu Jakuba Szipa, spisanym w 1589 roku w Bieczu (i był to jeden z dwóch szesnastowiecznych rejestrów, w których zostały one odnotowane), to najwięcej inwentarzy, w których wystąpiły agnuski pochodziło z XVII stulecia, a szczególnie z jego pierwszej połowy (9 na 14 spisów). Analiza inwentarzy pośmiertnych z małopolskich miasteczek pokazuje jednak, że agnuski przestały być notowane wraz z końcem tego stulecia, a w XVIII wieku zupełnie zniknęły z rejestrów ${ }^{22}$. Jednocześnie zauważa się, że tego typu artefakty częściej wspominane były w inwentarzach pochodzących z małopolskich miasteczek niż w rejestrach z Poznania spisanych w latach 1528-1635. Agnuski pojawiły się zaledwie w czterech poznańskich inwentarzach i, co warto podkreślić, w przeważającej większości były to zapisy pochodzące z lat dwudziestych i trzydziestych XVII stulecia ${ }^{23}$. Podobne zjawisko zaobserwował Dariusz Główka, badając inwentarze pośmiertne osób duchownych ${ }^{24}$.

Osoby sporządzające pośmiertne rejestry mienia zwracały uwagę na ilość agnusków, ich wielkość oraz rodzaj kruszcu, z którego je wykonano. Niektórzy mieszczanie, szczególnie ci zamieszkujący większe ośrodki miejskie, dysponowali większą liczbą ozdobnych medalików, ale nawet w tych przypadkach ich liczba nie przekraczała dwóch-trzech sztuk. Podobne zjawisko występowało w inwentarzach poznańskich ${ }^{25}$. W inwentarzach Rozesława Marcina Brzeskiego (1637), pisarza miejskiego z Szydłowca, czy bieckiego garncarza, Jana Bartoszowica (1643), pojawiły się po dwa agnuski wykonane ze srebra ${ }^{26}$. Wśród ruchomości, jakie pozostawiła właścicielka jatki rzeźniczej, Katarzyna Potrawczyna (1647) z Biecza, znalazły się również dwa agnuski, jeden „w srebro oprawny”, a drugi „,srebrny zupełnie” z wyrytymi na nim imionami Jezusa i Maryi. Jak pokazuje ten przykład, ozdobę agnusków

Agnusków zapomniana moc, stawa i piękno - rzecz o papieskim „,Agnus Dei”, „Seminare. Poszukiwania naukowe", 30/2011, s. 255-258.

19 ANK, Oddz. III, AmNS, sygn. 29/110/54, s. 372.

20 ANK, Oddz. I, Biecz, Księga ławnicza biecka 1585-1593, sygn. 29/101/0/2/10, s. 526.

21 J. Nowiński, op. cit., s. 245, 252-255; E. Letkiewicz, Klejnoty w Polsce. Czasy ostatnich Jagiellonów i Wazów, Lublin 2006, s. 234, 287-288.

22 Agnuski odnotowano w inwentarzach pośmiertnych pochodzących z ksiąg miejskich: Biecza, Kęt, Nowego Sącza, Pilzna, Szydłowca.

23 Stanowi to zaledwie $0,9 \%$ wszystkich opublikowanych rejestrów poznańskich, pochodzących z lat 1528-1635. Inwentarze mieszczańskie, op. cit., s. 349 [nr 341], s. 379 [nr 358], s. 448 [nr 397], s. 497 [nr 412 ].

24 D. Główka, Majątek osobisty duchowieństwa katolickiego w Koronie w XVII i XVIII wieku, Warszawa 2004, s. $183-184$.

25 W inwentarzach poznańskich notowano zwykle po dwa agnuski. Wyjątkowo w rejestrze mienia wspominanej już Elżbiety Topolskiej wystąpiły aż cztery srebrne agnuski (w tym trzy ,,agnuseczki maluchne”). Inwentarze mieszczańskie, op. cit., s. 448 [nr 397].

26 Biblioteka Czartoryskich w Krakowie (dalej: BCz), Akta wójtowskie i radzieckie Szydtowca 1614-1650 (dalej: Szydłowiec), sygn. 3907, s. 48; ANK, Oddz. I, Biecz, sygn. 29/101/0/2/17, s. 847. 
stanowiły nie tylko wizerunki Baranka Bożego czy Jana Chrzciciela, ale i święte imiona. Wśród licznych kosztowności należących do nowosądeckiego złotnika, Joachima Matuszowica (1631), wystąpił posrebrzany agnusek z wyrytym imieniem „Jezus"27. Przykłady źródłowe świadczą o tym, że w analizowanych źródłach mianem agnusków określano wszelkie medaliki, a nie tylko te z symbolicznym wizerunkiem Baranka ${ }^{28}$. Do Katarzyny Puszówny (1600), mieszkanki Nowego Sącza należał na przykład ,agnusek srebrny z jednej strony Pasja, a z drugiej św. Katarzyna z kołem"29.

Niektóre agnuski były bardzo ozdobne. Wśród ruchomości Agnieszki Toczonej (1601) z Pilzna znalazł się ,,agnusek pozłocisty z koralami, paciorków srebrnych między koralami dziesięć, a koralów dwadzieścia i siedm"30. Do Felicji Klimczykówny (1603), żony nowosądeckiego rajcy, należał ,agnusek, w którym jest baranek i Salvator, a na końcu perła wisi"31.

Kolejny rodzaj wymienianych w małopolskich inwentarzach pośmiertnych dewocjonaliów stanowiły różańce, występujące we wszystkich sygnalizowanych stuleciach. Pojawiały się one również w analizowanych przez Urszulę Sowinę spisach krakowskich, pochodzących z przełomu XV i XVI stulecia ${ }^{32}$. Dla województw krakowskiego i sandomierskiego tego typu artefakty wystąpiły w dziewięciu rejestrach pochodzących z XVI wieku (czyli w 5,3\% wszystkich spisów), w siedmiu spisach z XVII stulecia (1,75\% rejestrów) i w jednym osiemnastowiecznym rejestrze $\left(2 \%\right.$ spisów) ${ }^{33}$. Należy jednak zauważyć, że różańce najczęściej notowano w inwentarzach pośmiertnych pochodzących z XVI stulecia i tendencja ta dotyczyła zarówno spisów z Małopolski, jak i rejestrów poznańskich.

Tego typu dewocjonalia wykonywano najczęściej ze srebra i koralowca. Takie właśnie różańce wzmiankowano w rejestrach ruchomości należących do mieszkanek Pilzna: Magdaleny Madejowej z 1572 roku (,,pacierze koralowe ze srebrem”) ${ }^{34}$ oraz Katarzyny Koleczki $(1576)^{35}$. Do mieszkańca Kęt, Tomasza Curzydły (1695), obok dwóch agnusków (ze srebra i z mosiądzu), należał na przykład różaniec z czarnymi paciorkami, ozdobiony mosiężnym

27 ANK, Oddz. III, AmNS, Acta scabinalia 1630-1632, sygn. 29/110/47, s. 207.

28 ANK, Oddz. I, Biecz, sygn. 29/101/0/2/17, s. 1134-1135; J. Nowiński, op. cit., s. 246-252.

29 ANK, Oddz. III, AmNS, sygn. 29/110/24, s. 106. Podobnie w inwentarzu mieszkanki Poznania, Elżbiety Topolskiej (1629), wystąpił ,,agnusek srebrny, na którym Salvator z jedny strony, a z drugi Panna Maria”. Inwentarze mieszczańskie, op. cit., s. 448 [nr 397].

30 ANK, Oddz. I, Akta miasta Pilzna (dalej: Pilzno), Księga podwójcińsko-ławnicza Pilzna 1601-1609, sygn. 29/112/0/3/83, s. 58.

31 ANK, Oddz. III, AmNS, Acta scabinalia 1601-1604, sygn. 29/110/27, s. 891.

32 U. Sowina, Ubiór mieszczanek krakowskich $w$ świetle inwentarzy rzeczy z przełomu średniowiecza i nowożytności, w: Habitus facit hominem. Społeczne funkcje ubioru w średniowieczu i w epoce nowożytnej, red. E. Wółkiewicz, M. Saczyńska, M. Pauk, Warszawa 2016, s. 175.

33 W tym miejscu warto dodać, że wzmianki o agnuskach spotyka się w zapisach pochodzących z większych ośrodków miejskich tego regionu (Biecz, Kęty, Nowa Słupia, Nowy Sącz, Pilzno, Sandomierz, Skawina).

34 ANK, Oddz. I, Pilzno, Księga podwójcińsko-ławnicza Pilzna 1568-1576, sygn. 29/112/0/2/65, s. 703. Identyczne ,pacierze koralowe na poły [ze] srebrnemi, jabłko wielkie w nich” znajdowały się wśród ruchomości należących do Zofii Janowszczanki (1591) z Nowego Sącza. Ibidem, Oddz. III, AmNS, Acta scabinalia 1584-1593, sygn. 29/110/22, s. 492. Do mieszkańca Biecza, Marcina Fardy (1589), należały „koralowe pacierze”. ANK, Oddz. I, Biecz, sygn. 29/101/0/2/10, s. 517. Zob. E. Letkiewicz, op. cit., s. 264.

35 ANK, Oddz. I, Pilzno, sygn. 29/112/0/2/65, s. 855. 
agnuskiem $^{36}$. Jak widać, nie tylko krzyżyki, ale i różańce łączono z niezwykle popularnymi wówczas agnuskami.

Różańce wykonane ze srebra i koralowca dominowały nie tylko w spisach z Małopolski, ale i inwentarzach mienia mieszkańców Poznania ${ }^{37}$. Jednak tam różnorodność kamieni, z których produkowano różańce, była zdecydowanie większa, a obok srebrnych i z koralowca notowano różańce $\mathrm{z}$ jaspisu, górskiego kryształu czy tańszego gagatu ${ }^{38}$. W pojedynczych przypadkach w spisach małopolskich notowano różańce wykonane z bursztynu, jak w rejestrach mieszkanek Nowego Sącza - Felicji Klimczykówny (1603) i Anny Frankowiczówny (1678), do której należały „pacierze bursztynowe z krzyżykiem srebrnym”, połączone ze srebrny agnuskiem ${ }^{39}$.

Równie pieczołowicie notowano drobne elementy pochodzące z różańców. Wśród ruchomości Katarzyny Strzeszanki (1756) z Pilzna, obok ,paciorków prostych mównych”, wystąpił „portrecik Najświętszej P[anny] Częstochowskiej do paciorków”40. W spisie ruchomości innej mieszczki pilzneńskiej, Agnieszki Toczonej (1601), wystąpiło ,,jabłko srebrne od pacierzy wielkie"41. Podobne przykłady odnaleźć można również w spisach poznańskich. Po Jadwidze Gawronowej (1574) pozostało na przykład „kneflików od pacierzy kręconych 8”42.

W inwentarzach pośmiertnych zdecydowanie dominowały wzmianki o należących do zmarłych krzyżykach, agnuskach i różańcach. Innego rodzaju artefakty pojawiały się znacznie rzadziej. W grupie dewocjonaliów rzadziej wspominanych znajdowały się na przykład relikwiarze. Ponownie zjawisko to odnosiło się nie tylko do rejestrów spisywanych w małopolskich miasteczkach, ale i tych pochodzących ze zdecydowanie większego ośrodka miejskiego, jakim był Poznań, czy spisów mienia osób duchownych, analizowanych przez Dariusza Główkę ${ }^{43}$. W inwentarzach małopolskich tego typu precjoza gromadzili jedynie najbardziej zamożni mieszczanie, członkowie władz miejskich i ich bliscy, głównie mieszkańcy większych ośrodków miejskich w regionie (Biecz, Nowy Sącz, Sandomierz, Wieliczka). Relikwiarze notowano głównie w spisach pochodzących z pierwszej połowy XVII stulecia (cztery rejestry, czyli 1\% wszystkich inwentarzy spisanych w tym stuleciu) oraz w XVIII wieku (trzy spisy, stanowiące 6\% wszystkich osiemnastowiecznych rejestrów). Wśród kosztowności należących do Felicji Woleńskiej (1621) z Grybowa, żony tamtejszego rajcy i kupca, znajdował się na przykład „,relikwiarzyk srebrny”44. W inwentarzu miej-

\footnotetext{
36 ANK, Oddz. I, Akta miasta Kęty (dalej: Kęty), Księga radziecka Kęt 1688-1699, sygn. 29/107/0/2/19, s. 178, 179. Jadwiga Kocurkowa, której mienie spisano w Bieczu w 1599 roku, również posiadała różaniec ze srebra i korali z towarzyszącym im agnuskiem. ANK, Oddz. I, Biecz, Księga ławnicza biecka 1593-1603, sygn. 29/101/0/2/11, s. 730 .

37 Inwentarze mieszczańskie, op. cit., s. 31 [nr 48], s. 77 [nr 102], s. 88 [nr 128], s. 123 [nr 169], s. 133 [nr 179], s. 243 [nr 257], s. 312 [nr 316].

38 Inwentarze mieszczańskie, op. cit., s. 15 [nr 20], s. 31, 32 [nr 48], s. 126 [nr 179], 203 [nr 231], s. 262 [nr 275], s. 271 [nr 312]; I. Turnau, op. cit., s. 60.

39 ANK, Oddz. III, AmNS, Acta scabinalia 1676-1682, sygn. 29/110/63, s. 289. Warto również odnotować „paciorki bursztynowe, przy których kryształ biały okazały", należące do mieszkanki Pilzna, Reginy Siodlarki (1604). ANK, Oddz. I, Pilzno, sygn. 29/112/0/3/83, s. 209.

40 ANK, Oddz. I, Pilzno, Księga radziecka Pilzna 1756-1761, sygn. 29/112/0/2/58, s. 4.

41 ANK, Oddz. I, Pilzno, sygn. 29/112/0/3/83, s. 58.

42 Inwentarze mieszczańskie, op. cit., s. 147 [nr 194].

43 D. Główka, op. cit., s. 183.

44 ANK, Oddz. III, Księga radziecko-ławnicza Grybowa 1602-1638, sygn. 29/121/70, s. 379. W inwentarzu nowosądeckiego sukiennika, Kazimierza Paczkowica (1710), wystąpił „krzyż srebrny alias relikwiarz, w którym z obu
} 
skiego pisarza z Szydłowca, Rozesława Marcina Brzeskiego (1637), pojawiły się nawet dwa relikwiarze, jeden „,srebrny biały, drugi pozłocisty”45. Imponująca była liczba relikwiarzy, jakie zgromadził Jan Szczypkowski (1756), bednarz z Wieliczki. W rejestrze należących do niego ruchomości wymienione zostały aż dwadzieścia dwa relikwiarze. Niestety w większości odnotowano tylko ich kształty i wielkość, rodzaj zdobiących je ramek oraz fakt, że były chronione szkłem (,za szkłem puklastym duży 1”, ,za szkłem płaskim małych 2”, ,za szkłem okrągły mały”). Wiadomo, że pięć z nich przedstawiało Najświętszą Maryję Pannę („w zwierciadle”, „na blasze”, „w ramkach ołowianych”, „w ramkach cynowych w zwierciadle"), jeden św. Sebastiana i jeden św. Antoniego ${ }^{46}$.

Bywały również i takie dewocjonalia, które notowano jedynie w pojedynczych rejestrach. W rejestrze bieckiego rajcy, Pawła Śliwowskiego (1563), odnotowany został ,paternoster”, specjalny sznur modlitewny o luźnych końcach, służący do odmawiania modlitwy „Ojcze nasz", z określoną liczbą koralików, wykonanych z drewna lub kamieni szlachetnych. W przypadku Śliwowskiego chodziło o ,paternoster” wykonany z czerwonych korali i srebra ${ }^{47}$. Co ciekawe, doczekał się on wyceny i został oszacowany na 3 floreny ${ }^{48}$.

Warto odnotować także „,pacyfikał pozłocisty”, który pojawił się wśród ruchomości należących do nowosądeckiej mieszczki, Felicji Barwierki (1573), żony tamtejszego łaziebnika Marcina $^{49}$. W tym przypadku trudno jednoznacznie odpowiedzieć na pytanie, o jaki sprzęt liturgiczny chodziło. Czy w domu Felicji znalazł się używany podczas odprawiania Mszy świętej relikwiarz, w formie krzyża lub monstrancji, podawany wiernym do całowania, czy może był to ozdobny medalion zawierający relikwie świętych? ${ }^{50}$

Wśród ruchomości Jakuba Mogilańskiego (1653) z Nowego Sącza, wystąpiła „karawaka z relikwiami", czyli krzyż o specjalnej formie ${ }^{51}$. W powszechnym mniemaniu miał on moc chroniącą przed zarazą i klęskami żywiołowymi. Pojawienie się tego artefaktu w spisie wiązało się zapewne z dopiero co zakończoną w mieście epidemią morowego powietrza. Jednocześnie krzyż o dwóch poprzecznicach mógł być traktowany jako amulet przeciwko wszelkim nieszczęściom, a nie tylko zarazie ${ }^{52}$.

Według definicji Mariana Pisarzaka, mianem dewocjonaliów można określić również książeczki do nabożeństwa ${ }^{53}$. W inwentarzach pośmiertnych z małopolskich miast i miaste-

dwu stron są relikwie". Ibidem, AmNS, Acta consularia et scabinalia 1705-1712, sygn. 29/110/92, s. 727. Do Agnieszki Toporkowej (1659) z Sandomierza, żony tamtejszego rzeźnika należało natomiast ,pudełeczko z relikwiami”. Archiwum Państwowe w Sandomierzu (dalej: AP Sandomierz), Akta miasta Sandomierza (dalej: AmS), Księga ławnicza 1657-1660, sygn. 4, k. 358.

45 BCz Kraków, Szydłowiec, sygn. 3907, s. 48. „Relikwiarz wielki w samym srebrze” wymieniony został w rejestrze rzeczy, jakie pozostały po bieckim sukienniku Andrzeju Pindorze (1645). ANK, Oddz. I, Biecz, sygn. 29/101/0/2/17, s. 1054.

46 ANK, Oddz. III, Wieliczka, sygn. 29/117/18, s. 920.

47 ANK, Oddz. I, Biecz, Księga lawnicza biecka 1563-1566, sygn. 29/101/0/2/8, s. 8.

48 Ibidem, s. 41. Sznur modlitewny wykonany z czerwonych korali wystąpił również w inwentarzu innej mieszkanki Biecza, Zofii Prostakówny (1557). ANK, Oddz. I, Biecz, Księga ławnicza biecka 1556-1559, sygn. 29/101/0/2/6, s. 473 .

49 ANK, Oddz. III, AmNS, Acta scabinalia 1566-1574, sygn. 29/110/15, s. 566.

50 Pacyfikat, w: Słownik polszczyzny XVI wieku, t. 23: P-Przy, red. F. Pepłowski, Warszawa 1995, s. 10.

51 ANK, Oddz. III, AmNS, sygn. 29/110/54, s. 434.

52 M. Kołyszko, Dewocjonalia, op. cit., s. 41-61; idem, Wizerunki podwójnego krzyża w kulturze Polski, Toruń 2015; E. Letkiewicz, op. cit., s. 286.

53 M. Pisarzak, op. cit., kol. 1226. 
czek książki stanowiące część spuścizny nie były zbyt często notowane ${ }^{54}$. Natomiast w tych spisach, w których tytuły należących do mieszczan książek zostały wymienione, pojawiały się dzieła o tematyce religijnej oraz o dewocyjnym i użytkowym charakterze - Biblia, Nowy Testament, żywoty świętych, zbiory kazań, oficja, psałterzyki, rozmyślania, modlitwy błagalne (prekacje), modlitewniki maryjne. Rzadziej występowały książki o treści ascetycznej i mistycznej ${ }^{55}$. Nie ma tam jednak, jak w przypadku inwentarzy ksiąg lubelskich introligatorów, osobnych modlitewników przeznaczonych dla kobiet i mężczyzn czy podręczników dla bractw religijnych ${ }^{56}$. W inwentarzach małopolskich ,książki do modlenia się” wystąpiły w jednym spisie z XVI wieku oraz w jedenastu rejestrach pochodzących z XVII wieku, a także w dwóch spisanych w XVIII stuleciu ${ }^{57}$.

Osobną grupę stanowiły dewocjonalia zdobiące wnętrza mieszczańskich domów. Magdalena Bartkiewicz, analizując inwentarze mieszczańskie spisane w dużych ośrodkach miejskich, twierdziła, że niemal w każdym mieszczańskim inwentarzu występował, niekiedy misternie wykonany, krucyfiks ${ }^{58}$. O tym, że krucyfiksy pojawiały się w mieszczańskich domach, świadczyć mogą przykłady pochodzące z pojedynczych rejestrów mienia ubogich mieszczan krakowskich ${ }^{59}$. Natomiast w analizowanych inwentarzach z małopolskich miasteczek krucyfiksy zdobiące ściany mieszczańskich domów wymieniano niezmiernie rzadko. Podobnie pod tym względem wyglądały inwentarze poznańskie z lat 1528-1635, w których krucyfiksy również były notowane sporadycznie ${ }^{60}$. Identyczne tendencje zauważał również Dariusz Główka, analizując testamenty i inwentarze pośmiertne osób duchownych ${ }^{61}$.

\footnotetext{
54 K. Justyniarska-Chojak, Inwentarze pośmiertne, op. cit., s. 464-478; eadem, Testamenty i inwentarze pośmiertne z ksiąg miejskich województwa sandomierskiego (XVI-XVIII wiek), Kielce 2010, s. 173-174.

55 W inwentarzu Wojciecha Ochędożnego (1605) z Pilzna pojawił się tytuł „Desiderosus polskie książki in octavo", być może w tym przypadku chodziło o dzieło hiszpańskiego mistyka, opublikowane w drukarni Andrzeja Piotrkowczyka w 1589 roku. Zob. K. Justyniarska-Chojak, Inwentarze pośmiertne, op. cit., s. 473; E. Torój, Mieszczańskie kolekcje książek w siedemnastowiecznym Lublinie, „Folia Bibliologica” 2004/2005, vol. 52/53, s. 32-33.

56 E. Torój, Inwentarze książek lubelskich introligatorów z pierwszej połowy XVII wieku, Lublin 2000, s. 63, 79, 84, 94; eadem, Inwentarz księgozbioru Piotra Kliszewskiego lekarza lubelskiego z pierwszej połowy XVII wieku, „Folia Bibliologica” 1990/1991, vol. 38/39, s. 127.

57 Książki o takiej tematyce wystąpiły w inwentarzach pośmiertnych mieszkańców Biecza - Jakuba Szipa (1589), Stanisława Sternbergi (1604), Sebastiana Bariana Rokickiego (1606), Józefa Ziętka (1610), Michała Czaplicza (1612), a także Jakuba Małysza (Matysza) i Adama Karcikowskiego (1642) z Kęt oraz Reginy Halenowicowej (1636) z Nowego Sącza, Wojciecha Ochędorznego (1605) z Pilzna, Marcina konwisarza (1657) z Sandomierza, Rozesława Marcina Brzeskiego (1637) z Szydłowca. Dla XVIII wieku były to rejestry mieszkańców Wieliczki: Bartłomieja Kościńskiego (1728) i Jana Szczypkowskiego (1756). K. Justyniarska-Chojak, Inwentarze pośmiertne, op. cit., s. 464-478; eadem, Ksiażki w mieszczańskich inwentarzach pośmiertnych z terenu Małopolski (XVI-XVII wiek), w: Historia magistra vitae est... Studia z dziejów społeczno-gospodarczych i kulturalnych. Księga jubileuszowa dedykowana prof. zw. dr. hab. Wiesławowi Cabanowi z okazji 45-lecia pracy naukowej, red. L. Michalska-Bracha, M. Przeniosło, B. Wojciechowska, Kielce 2016, s. 57-66.

58 M. Bartkiewicz, Odzież $i$ wnętrza domów mieszczańskich $w$ Polsce $w$ drugiej połowie XVI $i$ w XVII wieku, Wrocław 1974, s. 69-70; E. Balcerzak, Metal Articles in Urban Households of 18th Century Poland, w: Omnia Res Mobilia. Polish Studies in Posthumous Inventories of Movable Property in the 16th-19th Century, ed. J. Kruppé, A. Pośpiech, Warsaw 1999, s. 137.

59 B. Bętkowska, J. Bieniarzówna, Inwentarze ruchomości ubogiego mieszczaństwa krakowskiego, „Kwartalnik Historii Kultury Materialnej”, 5,1957, s. 88 [nr 25] („krucyfiks drewniany”), s. 89 [nr 26] („krucyfiks na ścienie”), s. 90 [nr 29] (,,krucyfiks”).

${ }^{60}$ Inwentarze mieszczańskie, op. cit., s. 450 [nr 398], s. 533 [nr 415].

61 D. Główka, op. cit., s. 182-183.
} 
Zdecydowanie częściej niż krucyfiksy gromadzono „pasyjki”, przedstawiające figurę ukrzyżowanego Jezusa. W inwentarzu Elżbiety Brodziny (1650), mieszczki pilzneńskiej, odnotowana została na przykład ,pasyjka nad odrzwiami”62. W rejestrze pośmiertnym Jadwigi Lipnickiej, spisanym w Wieliczce w 1753 roku, wystąpiła ,pasja drewniana na stole stojąca"63. Dużą kolekcję i to cennych pasyjek zanotowano w rejestrze Jana Szczypkowskiego (1756), bednarza z Wieliczki. Wymieniono w nim bowiem trzy pasyjki, jedną „na postumencie czarno malowaną”, drugą „na postumencie posrebrzanym” oraz „pasję perłową macicą sadzoną"64.

Do rzadkości należało, aby mieszczanie z małopolskich miasteczek posiadali małe, przenośne ołtarzyki, występujące chociażby w zapisach mieszczan krakowskich. Służyły one do sprawowania Mszy świętej poza oficjalnym miejscem kultu, na przykład w czasie podróży. Mieszczanie krakowscy, uzyskując prawo do posiadania przenośnych ołtarzy, mogli z nich korzystać także w zaciszu własnego domu, w czasie choroby lub w celu pogłębiania pobożnych praktyk. Posiadanie tego przywileju było także ważne ze względów prestiżowych, nie tylko wyróżniało jego posiadacza na tle sąsiadów, ale i pozwalało mu na podkreślenie własnej pozycji w małej zamkniętej społeczności ${ }^{65}$. Tym bardziej interesujący może być przykład pochodzący z inwentarza mieszkańca Krakowa, Marcina Tempińskiego (1628), który do osób zamożnych raczej nie należał, ale dysponował „ołtarzykiem dziecinnym”66. $\mathrm{W}$ inwentarzach z małopolskich miasteczek tego rodzaju artefakt wystąpił jedynie w rejestrze mienia wspomnianego już kilkukrotnie Jana Szczypkowskiego (1756) z Wieliczki, do którego należał ołtarzyk ,snycerską robotą malowany"67.

W domach mieszczan pojawiały się obrazy o treści religijnej. Magdalena Bartkiewicz podkreślała, że wśród mieszkańców dużych miast szczególną popularnością cieszyły się wizerunki Najświętszej Maryi Panny (ukazanej często z Dzieciątkiem Jezus), przedstawienia Marii Magdaleny, Ewangelistów i licznych świętych (Józef, Jan), wizerunki Adama i Ewy oraz Anioła Stróża ${ }^{68}$. Wśród obrazów wiszących w mieszczańskich domach w Małopolsce zdecydowanie dominowały prace przedstawiające sceny z życia Jezusa lub wizerunki Najświętszej Maryi Panny ${ }^{69}$. Było to zjawisko typowe dla wszystkich inwentarzy pośmiertnych

\footnotetext{
62 ANK, Oddz. I, Pilzno, sygn. 29/112/0/3/73, s. 187.

63 ANK, Oddz. III, Wieliczka, sygn. 29/117/18, s. 799. Pasyjki często gościły w domach wielickich mieszczan, o czym świadczą przykłady z inwentarzy pośmiertnych - Bartłomieja Kościńskiego (1728), w którym wystąpiła „pasyjka mała”, czy Jacka Dobrzańskiego (1767), właściciela ,pasyjki z dzwonkiem”, wycenionej na 1 złoty i 15 groszy. Ibidem, Akta podkomorskie Wieliczki 1622-1772, sygn. 29/117/22, s. 115; ibidem, Wieliczka, Odpisy $i$ wypisy $z$ akt radzieckich wielickich 1764-1788, sygn. 29/117/19, s. 298.

64 ANK, Oddz. III, Wieliczka, sygn. 29/117/18, s. 920. W rejestrze pośmiertnym Franciszka Urydzyńskiego (1779) z Wojnicza wystąpiła „pasja stołowa, sedes u niej trupia głowa” oraz ,świętych Janów dwóch rżniętych”. Inwentarze mieszczan wojnickich 1589-1822, wyd. B. Trelińska, Wojnicz 1995, s. 98-99 [nr 71].

65 M. Saczyńska, Mieszczan krakowskich domowe świętości, op. cit., s. 283-285; eadem, Prywatna przestrzeń sakralna. Przykłady wykorzystywania oltarzy przenośnych w późnośredniowiecznej Polsce, w: Dom, majątek, klient, stuga. Manifestacja pozycji elit w przestrzeni materialnej i społecznej (XIII-XIX wiek), red. M.R. Pauk, M. Saczyńska, Warszawa 2010, s. 111-127.

66 B. Bętkowska, J. Bieniarzówna, op. cit., s. 90 [nr 29].

67 ANK, Oddz. III, Wieliczka, sygn. 29/117/18, s. 919-920.

68 M. Bartkiewicz, op. cit., s. 69-70.

69 Podobne zjawisko zaobserwowała Monika Saczyńska w przypadku obrazów znajdujących się w domach mieszczan krakowskich. Zob. M. Saczyńska, Mieszczan krakowskich domowe świętości, op. cit., s. 276-278.
} 
bez względu na miejsce ich spisania ${ }^{70}$. Do Sebastiana Bariana Rokickiego (1611) z Biecza należały trzy obrazy przedstawiające Najświętszą Maryję Pannę oraz sceny ukazujące mękę Chrystusa i złożenie Go do grobu ${ }^{71}$. W spisach występowały również wizerunki Ewangelistów oraz świętych patronów ${ }^{72}$. W rejestrze bieckiego rajcy Macieja Brodziszowica (1666) odnotowano dziewięć obrazów przedstawiających: Trójcę Przenajświętszą, Najświętszą Pannę Maryję, Trzech Króli oraz Ewangelistów (Mateusza, Łukasza, Marka) oraz świętą Zofię ${ }^{73}$.

Dewocjonalia pojawiały się wśród elementów masy spadkowej przekazywanej spadkobiercom, choć stanowiły specyficzną grupę ruchomości. Świadczyły o pewnych religijnych potrzebach testatorów czy o formach ich indywidualnej dewocji. Dla spadkobierców mogły mieć także walor sentymentalny, podtrzymując pamięć o zmarłych bliskich. Z drugiej strony wykonane z metali szlachetnych czy ozdobione drogocennymi kamieniami artefakty, przedstawiały konkretną wartość materialną. Tym większe zdziwienie może budzić fakt dość rzadkiego występowania w spisach tego rodzaju ruchomości. Jednocześnie należy zauważyć, że zjawisko to miało o wiele szerszy zasięg i nie ograniczało się tylko i wyłącznie do małopolskich miasteczek.

Nie można wykluczyć, że mała liczba inwentarzy, w których notowano tego rodzaju ruchomości, mogła wynikać z faktu przekazywania dewocjonaliów w formie legatów pobożnych na rzecz konkretnych instytucji kościelnych. W takiej sytuacji dewocjonalia nie trafiały do rąk spadkobierców i nie wchodziły w skład masy spadkowej notowanej w inwentarzach.

Być może mała ilość dewocjonaliów w rejestrach była wynikiem decyzji samych spadkobierców. Niektórzy bliscy mogli się bowiem decydować na zaopatrzenie zmarłych w używane przez nich za życia medaliki, różańce czy krzyżyki, wkładając im tego typu przedmioty do trumny. Zwyczaje takie praktykowane były w Gdańsku oraz w miastach hanzeatyckich, co opisywał Edmund Kizik i z pewnością występowały także w innych rejonach Rzeczypospolitej ${ }^{74}$.

Wiadomo, że osoby sporządzające pośmiertne rejestry mienia starały się z całą pieczołowitością spisywać co cenniejsze przedmioty składające się na masę spadkową, a wykonane ze srebra lub złota i ozdobione kamieniami szlachetnymi dewocjonalia zapewne do takich mobilów należały. Wielkość ośrodka miejskiego nie miała wpływu na staranność zapisu, a częstotliwość ich występowania w rejestrach zależała bezpośrednio od zamożności właścicieli spisywanego mienia. Część testatorów mogła też być zbyt uboga, aby stać ich było na zakup drogocennych artefaktów, co nie tłumaczy faktu rzadkiego występowania dewocjonaliów w inwentarzach. Można było przecież nabyć artefakty wykonane z tańszych materiałów, czego dowodzą analizowane rejestry. Wydaje się, że w przypadku dewocjonaliów

\footnotetext{
70 J. Motylewicz, Społeczeństwo Przemyśla w XVI i XVII wieku, Rzeszów 2005, s. 101-103; M. Gadocha, Testamenty i inwentarz Jadwigi i Marcina Mitkiewiczów. Przyczynek do dziejów mieszczaństwa krakowskiego, „Rocznik Lubelskiego Towarzystwa Genealogicznego", 2011, t. 3, s. 105; M. Saczyńska, Mieszczan krakowskich domowe świętości, op. cit., s. 275-278; M. Bartkiewicz, op. cit., s. 67; J. Dumanowski, Świat rzeczy szlachty wielkopolskiej w XVIII wieku, Toruń 2006, s. 151-154; D. Główka, op. cit., s. 184-186.

71 ANK, Oddz. I, Biecz, Księga ławnicza biecka 1603-1612, sygn. 29/101/0/2/12, s. 1011.

72 W inwentarzu Jana Bera (1601) z Nowego Sącza wymienione zostały obrazy przedstawiające św. Magdalenę oraz św. Urszulę. ANK, Oddz. III, AmNS, sygn. 29/110/27 s. 240.

73 Dwa obrazki określone mianem „,małych” ukazywały facies Salvatoris oraz ponownie Najświętszą Pannę. ANK, Oddz. I, Biecz, Księga radziecka biecka 1644-1693, sygn. 29/101/0/3/24, s. 747.

${ }^{74}$ E. Kizik, Wesele, kilka chrztów i pogrzebów. Uroczystości rodzinne w mieście hanzeatyckim od XVI do XVIII wieku, Gdańsk 2001, s. 197; M. Kołyszko, Dewocjonalia, op. cit., s. 11-12.
} 
badacz natrafia na inwentarzową „pułapkę oczywistości”, opisywaną i definiowaną przez Andrzeja Pośpiecha. Nawet z pozoru szczegółowe rejestry pośmiertne nie musiały być kompletne, co mogło być spowodowane wieloma czynnikami - nieumiejętnością sporządzenia tak drobiazgowych i czasochłonnych dokumentów, niekompetencją urzędników miejskich lub nieopłacalnością ich spisania. Jak pisał Andrzej Pośpiech, w przypadku inwentarzy pośmiertnych: „zwodniczość źródła jest jedną z zasadniczych jego cech”75.

\section{Bibliografia}

Źródła rękopiśmienne

Archiwum Kapituły Katedralnej Sandomierskiej:

Akta wójtowskie Nowej Słupi 1623-1644, sygn. 10.

Archiwum Narodowe w Krakowie, Oddz. I:

Akta miasta Biecza, Księga ławnicza biecka 1556-1559, sygn. 29/101/0/2/6; Księga ławnicza biecka 1579-1585, sygn. 29/101/0/2/9; Księga ławnicza biecka 1585-1593, sygn. 29/101/0/2/10; Księga ławnicza biecka 1593-1603, sygn. 29/101/0/2/11; Księga ławnicza biecka 1603-1612, sygn. 29/101/0/2/12; Księga ławnicza biecka 1639-1649, sygn. 29/101/0/2/17; Księga ławnicza biecka 1662-1677, sygn. 29/101/0/2/18; Księga radziecka biecka 1644-1693, sygn. 29/101/0/3/24.

Akta miasta Czchowa, Proconsularia, consularia, advocatialia et scabinalia 1698-1716, sygn. 29/104/0/2/30.

Akta miasta Kęty, Księga radziecka Kęt 1688-1699, sygn. 29/107/0/2/19.

Akta miasta Pilzna, Księga ławnicza Pilzna 1647-1654, sygn. 29/112/0/3/73; Księga radziecka Pilzna 1756-1761, sygn. 29/112/0/2/58; Księga podwójcińsko-ławnicza Pilzna 1568-1576, sygn. 29/112/0/2/65; Księga podwójcińsko-ławnicza Pilzna 1601-1609, sygn. 29/112/0/3/83.

Archiwum Narodowe w Krakowie, Oddz. III:

Akta miasta Nowego Sącza, Acta scabinalia 1566-1574, sygn. 29/110/15; Acta scabinalia 1584-1593, sygn. 29/110/22; Acta scabinalia (iudiciaria criminalia) 1590-1604, sygn. 29/110/24; Acta scabinalia 1601-1604, sygn. 29/110/27; Acta scabinalia 1625-1628, sygn. 29/110/45; Acta scabinalia 1630-1632, sygn. 29/110/47; Acta scabinalia 1641-1645, sygn. 29/110/50; Acta scabinalia 1647-1649, sygn. 29/110/52; Acta scabinalia 1651-1658, sygn. 29/110/54; Acta scabinalia 1666-1669, sygn. 29/110/59; Acta scabinalia 1671-1675, sygn. 29/110/62; Acta scabinalia 1676-1682, sygn. 29/110/63; Acta scabinalia 1689-1694, sygn. 29/110/88; Acta consularia et scabinalia 1705-1712, sygn. 29/110/92.

Akta miasta Wieliczki, Akta podkomorskie Wieliczki 1622-1772, sygn. 29/117/22; Odpisy i wypisy z akt radzieckich wielickich 1614-1763, sygn. 29/117/18; Odpisy i wypisy z akt radzieckich wielickich 1764-1788, sygn. 29/117/19.

Księga ławnicza miasta Skawiny (protokół mniejszy) w późniejszych latach radziecko-ławnicza 1661-1667, sygn. 29/114/17.

Księga radziecka miasta Skawiny (protokół) 1577-1614, sygn. 29/114/19.

Księga radziecko-ławnicza Grybowa 1602-1638, sygn. 29/121/70.

Archiwum Państwowe w Sandomierzu:

75 A. Pośpiech, Pułapka oczywistości. Pośmiertne spisy ruchomości szlachty wielkopolskiej z XVII wieku, Warszawa 1992, s. 47. 
Akta miasta Sandomierza, Księga ławnicza 1657-1660, sygn. 4; Księga radziecka 1628-1641, sygn. 10.

Biblioteka Czartoryskich w Krakowie:

Akta wójtowskie i radzieckie Szydłowca 1614-1650, sygn. 3907.

Źródła drukowane

Bętkowska B., Bieniarzówna J., Inwentarze ruchomości ubogiego mieszczaństwa krakowskiego, „Kwartalnik Historii Kultury Materialnej”, 5/1957, s. 76-99.

Gdański inwentarz mienia domowego Magdaleny Szumanowej z 1706 roku, oprac. i wyd. A.R. Chodyński, H. Dwilewicz, Wrocław-Warszawa-Kraków 1984.

Groicki B., Obrona sierot i wdów, oprac. K. Koranyi, Warszawa 1958.

Groicki B., Porzadek sąów i sprawa miejskich prawa majdeburskiego w Koronie Polskiej, oprac. K. Koranyi, Warszawa 1953.

Inwentarze mieszczan wojnickich 1589-1822, wyd. B. Trelińska, Wojnicz 1995.

Inwentarze mieszczańskie z lat 1528-1635 z ksiag miejskich Poznania, wyd. S. Nawrocki, J. Wisłocki, Poznań 1961.

Inwentarze mieszczańskie z XVIII wieku z ksiag miejskich i grodzkich Poznania, t. 1: Z lat 1700-1758, wyd. J. Burszta, C. Łuczak, Poznań 1962.

Inwentarze mieszczańskie z XVIII wieku z ksiag miejskich i grodzkich Poznania, t. 2: 1759-1793, wyd. J. Burszta, C. Łuczak, Poznań 1965.

Opracowania

Agnusek, w: Słownik polszczyzny XVI wieku, t. 1: A-Bany, red. S. Bąk, M. R Mayenowa, F. Pepłowski, Wrocław-Warszawa-Kraków 1966, s. 91.

Bartkiewicz M., Odzież $i$ wnętrza domów mieszczańskich $w$ Polsce $w$ drugiej połowie XVI $i$ w XVII wieku, Wrocław 1974.

Balcerzak E., Metal Articles in Urban Households of 18th Century Poland, w: Omnia Res Mobilia. Polish Studies in Posthumous Inventories of Movable Property in the 16th-19th Century, ed. J. Kruppé, A. Pośpiech, Warsaw 1999, s. 107-148.

Dumanowski J., Świat rzeczy szlachty wielkopolskiej w XVIII wieku, Toruń 2006.

Gadocha M., Testamenty i inwentarz Jadwigi i Marcina Mitkiewiczów. Przyczynek do dziejów mieszczaństwa krakowskiego, „Rocznik Lubelskiego Towarzystwa Genealogicznego”, 2011, t. 3, s. 98-121.

Główka D., Majątek osobisty duchowieństwa katolickiego w Koronie w XVII i XVIII wieku, Warszawa 2004.

Justyniarska-Chojak K., Inwentarze pośmiertne z małych i średnich miast Małopolski (w XVI-XVIII wieku), Kielce 2020.

Justyniarska-Chojak K., Książki w mieszczańskich inwentarzach pośmiertnych z terenu Małopolski (XVI-XVII wiek), w: Historia magistra vitae est... Studia z dziejów spoteczno-gospodarczych i kulturalnych. Ksiega jubileuszowa dedykowana prof. zw. dr. hab. Wiesławowi Cabanowi z okazji 45-lecia pracy naukowej, red. L. Michalska-Bracha, M. Przeniosło, B. Wojciechowska, Kielce 2016, s. 57-66.

Justyniarska-Chojak K., Testamenty i inwentarze pośmiertne z ksiag miejskich województwa sandomierskiego (XVI-XVIII wiek), Kielce 2010. 
Kizik E., Wesele, kilka chrztów i pogrzebów. Uroczystości rodzinne w mieście hanzeatyckim od XVI do XVIII wieku, Gdańsk 2001.

Kołyszko M., Dewocjonalia z końca XVI-XVIII wieku pochodzace z badań archeologicznych na terenie Polski (stan zachowania, identyfikacja, zagadnienia konserwatorskie), Toruń 2013.

Kołyszko M., Wizerunki podwójnego krzyża w kulturze Polski, Toruń 2015.

Letkiewicz E., Klejnoty w Polsce. Czasy ostatnich Jagiellonów i Wazów, Lublin 2006.

Motylewicz J., Społeczeństwo Przemyśla w XVI i XVII wieku, Rzeszów 2005.

Nowiński J., Agnusków zapomniana moc, sława i piękno - rzecz o papieskim „Agnus Dei”, „Seminare. Poszukiwania naukowe”, 30/2011, s. 245-267.

Pacyfikat, w: Słownik polszczyzny XVI wieku, t. 23: P-Przy, red. F. Pepłowski, Warszawa 1995, s. 10.

Pisarzak M., Dewocjonalia, w: Encyklopedia katolicka, t. 3, red. R. Łukaszyk, L. Bieńkowski, F. Gryglewicz, Lublin 1985, kol. 1226.

Pośpiech A., Pułapka oczywistości. Pośmiertne spisy ruchomości szlachty wielkopolskiej z XVII wieku, Warszawa 1992.

Saczyńska M., Mieszczan krakowskich domowe świętości, czyli wyobrażenia dewocyjne w przestrzeni prywatnej (przykłady wczesnonowożytne), w: Rzeczy i ludzie. Kultura materialne w późnym średniowieczu i w okresie nowożytnym. Studia dedykowane Marii Dąbrowskiej, red. M. Bis, W. Bis, Warszawa 2014, s. 275-286.

Saczyńska M., Prywatna przestrzeń sakralna. Przykłady wykorzystywania oltarzy przenośnych w późnośredniowiecznej Polsce, w: Dom, majatek, klient, sługa. Manifestacja pozycji elit w przestrzeni materialnej i społecznej (XIII-XIX wiek), red. M.R. Pauk, M. Saczyńska, Warszawa 2010, s. 111-127.

Sowina U., Ubiór mieszczanek krakowskich w świetle inwentarzy rzeczy z przełomu średniowiecza i nowożyności, w: Habitus facit hominem. Społeczne funkcje ubioru w średniowieczu $i$ w epoce nowożytnej, red. E. Wółkiewicz, M. Saczyńska, M. Pauk, Warszawa 2016, s. 163-177.

Torój E., Inwentarze książek lubelskich introligatorów z pierwszej połowy XVII wieku, Lublin 2000.

Torój E., Inwentarz księgozbioru Piotra Kliszewskiego lekarza lubelskiego z pierwszej połowy XVII wieku, „Folia Bibliologica”, 1990/1991, vol. 38/39, s. 123-143.

Torój E., Mieszczańskie kolekcje książek w siedemnastowiecznym Lublinie, „Folia Bibliologica", 2004/2005, vol. 52/53, s. 19-37.

Turnau I., Słownik ubiorów. Tkaniny, wyroby pozatkackie, skóry, broń i klejnoty oraz barwy znane w Polsce od średniowiecza do początku XIX w., Warszawa 1999. 